\title{
Determination of anxiety, mood disorders and disability in cluster and migraine headache
}

\author{
C Gonzalez*, S Benitez, T Gomez, M Bernal, MD Jimenez \\ From The European Headache and Migraine Trust International Congress \\ London, UK. 20-23 September 2012
}

\begin{abstract}
Introduction
Headache is the most frequent pathology in neurology. Migraine is very frequent in the population and it is a disease of young people, with repercussion in their social life and in their job and with important expenses. In cluster headache the pain is very severe and disabling. The patients have difficulties in having a normal life and are often absent in their jobs - some of them even lose their employment - and very frequently use symptomatic and very expensive treatments. All of the above mentioned causes severe anxiety, mood disorders and disabilities to these patients.
\end{abstract}

\section{Method and objectives}

In order to quantify those effects and to determine quantitative measures of depression, anxiety and disability we applied the "Hamilton Depression rating Scale" test and the "Hamilton Anxiety Rating Scale", a generic instrument for determining quality of life "SF36-2" and a headache specific instrument of disability "MIDAS test". We study 54 patients with cluster (17 chronic cluster and 37 episodic cluster) and 80 with migraine (40 chronic migraine and 40 episodic migraine). Result: Anxiety and depression are more important in chronic migraine and cluster than in episodic forms. MIDAS test results are more affected in chronic forms due to the higher frequency of headache episodes. In the SF36, we can see that these patients have disability in multiple fields, more important in chronic forms. We compare every field in two different kind of headache.

\section{Conclusion}

Cluster and migraine are diseases very disabling and with repercussion in the patients life, specially in chronic forms. They lose jobs and money, with very

Virgen del Rocio Universitary Hospital, Spain important consequencies for them and their families. It is important to recognize these symptoms to offer better therapies and multidisciplinary management to our patients.

Published: 21 February 2013

\section{References}

1. Abbass A, Lovas D, Purdy A: Direct diagnosis and management of emotional factors in chronic headache patients. Cephalalgia 2008, 28(12):1305-14.

2. Jürgens TP, Gaul C, Lindwurm A, Dresler T, Paelecke-Habermann $Y$, Schmidt-Wilcke T, Lürding R, Henkel K, Leinisch E: Impairment in episodic and chronic cluster headache. Cephalalgia 2011, 31(6):671-82.

doi:10.1186/1129-2377-14-S1-P103

Cite this article as: Gonzalez et al:: Determination of anxiety, mood disorders and disability in cluster and migraine headache. The Journal of Headache and Pain 2013 14(Suppl 1):P103.

\section{SpringerOpen $^{\odot}$}

(c) 2013 Gonzalez et al; licensee Springer. This is an Open Access article distributed under the terms of the Creative Commons Attribution License (http://creativecommons.org/licenses/by/2.0), which permits unrestricted use, distribution, and reproduction in any medium, provided the original work is properly cited.
Submit your manuscript to a SpringerOpen ${ }^{\circ}$ journal and benefit from:

- Convenient online submission

- Rigorous peer review

- Immediate publication on acceptance

- Open access: articles freely available online

- High visibility within the field

- Retaining the copyright to your article

Submit your next manuscript at $>$ springeropen.com 